\section{West German universities}

SIR-With nearly six years experience of the present "democratic" system in one West German university and after working for 10 years in a US university (JVB) and 28 years in a UK university (GE), we believe that Stumpfl (Nature 319, 256; 1986) overstates its deficiencies.

The "democratic" committees (on which professors constitute only 50 per cent of the membership, even for the appointment of new professors) are, as he claims, immensely time-consuming and inefficient. However, they provide an opportunity, perhaps the only one, for students to counter the all-pervading attitude that the university exists primarily to support the administration or the teachers rather than to educate the students. It is the rule rather than the exception that professors allow only one hour a week for individual contact with students (the weekly Sprechstunde); and there is frequently also little informal contact between professors within one faculty or with the lecturers, there being no equivalent to the regular "lunchtime gettogether" or the "common room".

In our experience, the committees are not "...dominated by extreme left-wing activists". The real power lies with one individual in the faculty, the dean and his tiny committee, the Dekanat. $\mathrm{He}$ is responsible for all administrative duties (for example the teaching programme, financial expenditure, the supervision of the lecturers, the allocation of space, arranging for the appointment of new professors, safety, appeals against examination procedures or results).

Since these duties are so arduous (and incompatible with full-time teaching or research), the office is generally held for only one or two years - hardly long enough to learn how to perform the duties competently. Being ultimately responsible but insufficiently experienced, the dean may indeed adopt "populist measures" or have to "bow to the majority of the less qualified" to obtain committee decisions required to keep the faculty running.

Meanwhile, each professor is explicitly expected by all those who work with/ under him to advocate lines of action that will afford maximal gain to his particular section of the faculty; hence, selfinterested pleading rather than consideration of the overall good characterizes the interminable committee discussion; and the dean, who may not himself be entirely disinterested, lacks the experience to hold out against merely clever arguing.

On this analysis, it is not the "democratic" system in itself that is at fault. Rather, the purposes of the university have been lost sight of (partly due to the sheer weight of the administrative paper work); and the day-to-day administration falls to those who do not remain in office long enough to learn to withstand those who push hardest.

University of Bielefeld

JOSEPHINE V. BROWN

George ETTLINGER

4800 Bielefeld 1, FRG

\section{South Africa}

SiR-Would it be too much to hope for a cool and rational discussion of the issues raised by the banning of South Africans from the World Archaeological Congress? While there is indeed an issue of principle involved, as Bender et al. insist (Nature 319, 532; 1986), the decision about what action to take should be made with a view to what is most likely to be effective.

It is presumably this which lies behind the idea of "historical moments" in the lives of repressive governments, and makes it worth serious consideration. However, it also undermines the attempt of Bender and his colleagues to treat South Africa as uniquely awful because it institutionalizes apartheid. Mandelstam et al. (Nature 319, 715; 1986) are right to condemn them for failing to address the real issue. But they go on to ridicule the use of the "historical moments" argument against South Africa on the grounds that logically we should apply it to many other regimes as well. Although some of the examples they cite are strange - the only "mass slaughters that take place constantly in the Middle East" that I know of are part of the Iran-Iraq war, and they seem unaware of the recent change of government in Uganda - there is every reason for being prepared to treat other repressive regimes in the same way as South Africa's.

There is no doubt that the attitude to South Africa of the left in Britain has long been distorted by hypocritical double standards. South Africa is very far from being the nastiest country in the world, or even in Africa.

That said, there is a better prima facie argument for singling out South Africa at this particular moment than is acknowledged by Mandelstam et al. It does have democratic structures and institutions of a kind, and, pace Dr Slabbert, a legitimate opposition, and is thus more likely than, say, Paraguay or Syria to respond to boycotts and bans because, unlike them, it has a body politic capable of feeling the pressure.

We should forget the shoddy behaviour and dubious motives characteristic of so many of apartheid's foreign opponents among the fashionable left, and instead concentrate on what is most likely to bring about desirable change in South Africa, and in the much more vicious regimes to be found in almost every continent.

A. W. Anderson

University of Oxford,

Department of Biological Anthropology, 58 Banbury Road,

Oxford $O X 26 Q S, U K$

SIR-The recent letter from Bender et al. (Nature 319, 532; 1986) supporting the Southampton boycott of South African archaeologists is basically a purely political document, apparently expressing the view that the Botha government will tremble in its shoes when enlightened academics stamp their feet. If only this proposition were true. The arguments presented appear to place little value on either scientific or educational considerations. However as the letter comes from a university address, one must presume its writers are educationists, and so should be willing to state their position clearly as regards educational issues.

As a pragmatic scientist and university teacher, it seems to me their position as educationists must be one of the following:

(1) It is wrong to provide good quality universities in South Africa. If this is the stance, its basis presumably is that black people do not need a university education. (2) It is right to provide good quality universities in South Africa, but those who do so should be penalized for their efforts. This stance seems to be straightforwardly contradictory.

(3) It is all right to provide undergraduate education in South Africa, but postgraduate education and research should not take place there. If this is the stance, it presumably means that the appropriate ceiling for black people is an undergraduate degree - which is just a sophisticated version of Dr Verwoerd's vision that they should be educated so far and no further.

(4) Both undergraduate and graduate university education should be available to blacks in South Africa, but not to whites. This stance is both racist and eminently unpractical in terms of educational realities. If this is indeed the stand taken, who will do the teaching, and where will the necessary reservoir of high-level academics come from?

In view of the destructive nature of their stance, your correspondents have an obligation to make their position clear. I should very much like to know which of these alternatives they support (or what other view they have of the education that should be available to the populace of this country).

George F. R. Ellis Department of Applied Mathematics, University of Cape Town,

Rondebosch, Cape 7700,

South Africa 